\title{
Article \\ Estimating Total Energy Expenditure for Fire-Fighters during Large Scale Disaster Response Training Using a Tri-Axial Accelerometer
}

\author{
Nao Koizumi ${ }^{1}\left(\mathbb{D}\right.$, Yutaro Negishi $^{1}{ }^{\text {, Hitomi Ogata }}{ }^{2}$, Randeep Rakwal $^{3}{ }^{(D)}$ and Naomi Omi ${ }^{3, *}$ \\ 1 Graduate School of Comprehensive Human Sciences, University of Tsukuba, 1-1-1 Tennodai, \\ Tsukuba 305-8574, Japan; s1830459@s.tsukuba.ac.jp (N.K.); negiro424@gmail.com (Y.N.) \\ 2 Graduate School of Humanities and Social Sciences, Hiroshima University, Higashi-Hiroshima, \\ Hiroshima 739-8521, Japan; hogata@hiroshima-u.ac.jp \\ 3 Faculty of Health and Sport Sciences, University of Tsukuba, 1-1-1 Tennodai, Tsukuba 305-8574, Japan; \\ plantproteomics@gmail.com \\ * Correspondence: omi.naomi.gn@u.tsukuba.ac.jp; Tel.: +81-29-853-6319
}

check for updates

Citation: Koizumi, N.; Negishi, Y.; Ogata, H.; Rakwal, R.; Omi, N. Estimating Total Energy Expenditure for Fire-Fighters during Large Scale Disaster Response Training Using a Tri-Axial Accelerometer. Nutrients 2021, 13, 2789. https://doi.org/ $10.3390 /$ nu13082789

Academic Editor:

Alessandro Sartorio

Received: 2 July 2021

Accepted: 10 August 2021

Published: 14 August 2021

Publisher's Note: MDPI stays neutral with regard to jurisdictional claims in published maps and institutional affiliations.

Copyright: (c) 2021 by the authors. Licensee MDPI, Basel, Switzerland. This article is an open access article distributed under the terms and conditions of the Creative Commons Attribution (CC BY) license (https:/ / creativecommons.org/licenses/by/ $4.0 /)$.

\begin{abstract}
The present study was conducted to estimate total energy expenditure (TEE) of fire-fighters using tri axial-accelerometers in conjunction with an activity log survey on a large number of subjects undergoing training mimicking a large-scale disaster. Subjects were 240 fire-fighters participating in a two-day fire-fighting training dedicated to large-scale natural disasters. Data was analyzed by job type of activity group and the job rank, and by comparing the average. The average TEE of the total survey training period is about $3619( \pm 499) \mathrm{kcal}$, which is the same value of expenditure for professional athletes during the soccer game season. From the activity group, the rescue and other teams consumed significantly more energy than the fire and Emergency Medical Team (EMS) teams. From the job rank, Fire Captain (conducting position) consumed significantly lower energy than the Fire Lieutenant and Fire Sergeant. Furthermore, it was found that a middle position rank consumed the most energy. This research supports a need to reconsider the current rescue food (and protocols) to supplement the energy expenditure of fire-fighters. In addition, since there was a significant difference between the job type and the job rank, it is necessary to examine the energy amount and shape suitable for each.
\end{abstract}

Keywords: energy expenditure; tri-axis accelerometer; high-level physical activity; energy required for firefighters

\section{Introduction}

When a large disaster occurs, fire-fighters are expected to engage in disaster rescue activities of high intensity and for a long period under harsh environmental conditions. The first $48 \mathrm{~h}$ after the disaster are especially critical, as the priority is on the saving victims' lives and this is the time period where the fire-fighters usually work without sleep and rest. In Japan, when a large-scale disaster occurs, emergency fire response teams are organized by the fire department and fire-fighters are dispatched nationwide for various disaster-relief activities; this implies working away from the home base and the necessity of transporting all necessary fire-fighting equipment and resources in order to carry out multiple duties longer than usual duty hours.

A critical requirement in disaster-relief operations comes down to a very basic requirement, namely food or 'nutrition' for the fire-fighters. "Food" is especially required to maintain the body condition of fire-fighters in such emergency situations, and supporting them for their enhanced role as rescue personnel in the disaster zone. Under such highintensity work/abnormal situations it is understandable that there might be a less than sufficient food supply and this lack of food (energy) creates an adverse effect on the firefighters. A recent study has looked into the indices of metabolic and cardiovascular health 
in wildland fire-fighters, pre- and post-season maladaptive changes in adipose tissue, blood lipids and hepatic function [1]. Akano et al. (2013) reported that about half of fire-fighting personnel showed 'poor physical condition' during the Great East Japan earthquake in 2011 [2]. A report from the Fire and Disaster Management Agency issued in 2012 revealed that it is the responsibility of each fire department to make food, water, personal equipment, etc., available for more than $72 \mathrm{~h} \mathrm{[3].} \mathrm{However,} \mathrm{complying} \mathrm{with} \mathrm{this} \mathrm{condition} \mathrm{is} \mathrm{difficult,}$ and it was found that the stockpile of each fire department headquarters is not sufficient [4]. The same research also noted that the fire department needed other technical information such as the energy requirements of fire-fighters, which has a role in preparing the appropriate food [4]. With regards to the energy intake, it was reported that the fire-fighters consumed an inadequate amount of total calories, including some nutrients, compared to a military dietary reference intake [5]. These studies also led us to question and find out how much energy is consumed in the actual activity for the preparation during an actual disaster. The firefighters have different roles (activities) depending on their positions, and it was hypothesized that there would be differences in energy consumption. Moreover, based on the division of roles and the command system [6], it is our belief that there needs to be a comparison by job type of activity group and the job rank.

Japan is one of the countries most affected by natural disasters such as typhoons, heavy rain, floods, landslides, earthquakes, tsunami, snow and volcanic eruptions, etc. [7]. Largescale disasters in Japan usually result in multiple damages across both rural and urban areas, ranging from mountainous to coastal areas. Therefore, large-scale disasters cause various accidents for example huge fires, building collapses, flood damages, landslides, etc. Japanese fire departments provide a variety of services, such as fire-fighting, emergency medical service (EMS), rescue service and backup units in the event of a disaster. A National Fire Service Team for Disaster Response (NFSTDRT) is usually created by the Japanese government immediately following a large disaster. The NFSTDRT was founded in 1995, after the Great Hanshin-Awaji Earthquake and institutionalized by the Fire Defense Organization Law, as amended in 2003. Officially, NFSTDRT was founded in 2004 [3]. Since 2004, the Commissioner of the Fire and Disaster Management Agency has the authority to mobilize and control fire-fighting teams in the event of a large-scale disaster or accident [3]. In the case of the Great East Japan Earthquake, for the first 88 days of 11 March 2011 to 6 June 2011, the emergency fire-fighting support team constituted of a total of 30,684 personnel and carried out numerous disaster response activities. In addition, from the lessons learned from the Great East Japan Earthquake [8], the Japanese government indicated that the number of emergency fire-fighting support team registered targets will be significantly increased to 6000 units in 2018, for the purpose of strengthening the response to the next large disaster [9]. Therefore, more and more emergency fire assistance teams will be registered in the future, and the number of instances where many officers to be dispatched to affected areas as emergency fire responses brigades will increase. As the need for a NFSTDRT is projected to increase in the future, it is expected that it will become increasingly important to understand the members' activities and manage those activities in light of the available information.

Due to logistic issues and costs, the fire-fighters' field survey has been limited todate [10]. For example, the use of the double-labeled water (DLW) test as the gold standard for the measurement of total energy expenditure (TEE) is expensive, and also requires a lot of time other than disaster activities during the study period. Total energy expenditure at the time of disaster activity is presumed to be about 3000 to $4900 \mathrm{kcal}$ from a literature review research [10-13]. The TEE that has been reported is calculated from a small number of participants, and there is no report on using a large participation group. Omi et al. (2014) [14] estimated that the energy requirement of fire-fighters in the event of a largescale disaster is about 3000 to $4000 \mathrm{kcal}$, but it is difficult to determine accurately at present due to a wide range of estimated values. Omi et al. (2014) [14], Parker et al. (2017) [15], and Robertson et al. (2017) [16] tried to verify the physical activity of firefighters using new equipment, but the number of samples remained small. Fire-fighters 
have various roles during a large-scale disaster activity, but there are only a few cases where they are quantitatively verified. In addition, these are the results of data from the fire-fighters only. The data on other personnel such as the paramedics and rescue staff who also work alongside the fire-fighters at disaster sites has not been collected or analyzed, and remains unclear. Furthermore, all ranks cannot take part in these disaster-related activities; moreover, their activity level is different depending on the job position and job rank. Nevertheless, the authors have not been able to find these reports for verification and clarification. Therefore, in this research, the focus was on the measurement of a large number of participants simultaneously, using the accelerometer (AC) method that is actually wearable, and which can divide the time for each activity. Furthermore, we aimed to clarify the characteristics of each type of activity team and by job rank.

Based on the above facts and gaps in research, it is essential for fire-fighters to not only know but also understand their energy expenditure demands during an emergency disaster response management. The aim of this study was therefore to estimate the TEE of fire-fighters by utilizing the accelerometers on a large number of subjects mimicking a large-scale disaster. Therein, the research questions were formulated as: (i) What is the average TEE of fire-fighters during a large-scale disaster activity training? and, (ii) What are the characteristics of the required energy in each job rank and activity group? To fulfil this aim, the scope of study will be delineated to assess the training of large-scale disaster activities. This training is conducted in a masked format that does not reveal the contents to the participants in advance, so it can be said that this training is close to a real disaster. It is anticipated that findings from this research will also provide an academic base to update the rescue food that could support fire-fighters in emergency situations.

\section{Materials and Methods}

\subsection{Approach}

A survey- and questionnaire-based approach was used to estimate the energy expenditure of fire-fighters using the tri-axis accelerometer and activity log records. This study was conducted with the approval of the University of Tsukuba Physical Education Research Ethics Committee (Number: T28-66, Study on the activity and nutrition of Fire service in disaster response, approved 3 October 2016).

\subsection{Training and Participants}

\subsubsection{Survey Target Training}

The study targeted fire-fighters comprising a total of 241 research subjects participating in the five 2-day disaster simulation training (i.e., fire-fighters do not know what is in the training protocol). This study carried out five cross-sectional surveys of diverse category research subjects in different situations. The purpose of this research was to calculate a value closer to the actual value by conducting multiple surveys and averaging them. The reason was because each actual disaster has a different weather condition and associated damage. Long-term training was conducted with assumptions that are close to real disasters and whose contents are not informed to participating members in advance. Although it is desirable to measure with an actual disaster, when an actual disaster occurs, there is urgency and it is impossible to attach the devices and perform the measurements. Furthermore, because it is unpredictable, we targeted disaster simulation training which is considered to be the most similar to a real disaster (Appendix A).

\subsubsection{Participants}

241 officers from 28 fire departments of seven prefectures across Japan were recruited to participate in this study. Males, selected as part of the training members of the National Fire Service Team for Disaster Response, were members who were in good health, passed the physical fitness test at the time of hiring and had completed basic education (excluding those who have been in service for less than half a year). The participants were randomly selected by the head of each institution, which consented to their participation in the 
survey after the list of participants for each training subjects to the survey was prepared. All participants $(\mathrm{n}=241)$ were male with a mean age of $35 \pm 7.3$ years, height of $172.5 \pm 5.5 \mathrm{~cm}$, weight of $69.7 \pm 7.8 \mathrm{~kg}$, and Body Mass Index (BMI) of $23.4 \pm 2.1 \mathrm{~kg} / \mathrm{m}^{2}$. They were organized into rescue, firefighting, EMS and the other teams (the command and back up unit). Each officer is classified by job rank (Fire captain, Fire Lieutenant, Fire Sergeant, Assistant Fire Sergeant and Fire Fighter) (Table 1). Participants were informed and agreed to the details of this study. In addition, a detailed explanation was given to each training director and each participating organization affiliated institution on the purpose and contents of the experiment, and this was started with an agreement.

\subsection{Procedures and Instrumentation}

Demographic data (i.e., body height, body mass, age) for each subject was obtained via a questionnaire. Each subject was required to wear a tri-axial accelerometer (Omron activity meter Active style PRO HJA-750C-23 g, $40 \times 52 \times 12$ mm; OMRON, Kyoto, Japan) as an evaluation method of the AC method during the targeted training.

\subsection{Validation of Accelerometer Placement}

In previous research, the position of the accelerometer (Active style Pro HJA-750C) is indicated as to be strapped on the waist [17]. Moreover, there were cases where the accelerometer was secured on the waist belt [18] or carried in the chest pocket [10]. The rationale for waist placement is based on the assumption that the movement of the center of gravity of the body is associated with physical energy expenditure. On the other hand, Heil (2002) had also tried to estimate the TEE of a firefighter by attaching it to the chest part [10].

In disaster activities like those used for the disaster simulation training targeted in the present study, it is expected that officers will wear fire-resistant clothes on top of standard activity clothes. Furthermore, when searching for refugees in the debris of the disaster site, the officers move in such a way so as to bend their posture to the narrow part. Thus, there is a possibility of breaking the equipment when it is attached on the outside and the possibility of it detaching unintentionally may happen. Therefore, we considered placing the device on the chest area. The base part of the chest pocket (length $16.2 \mathrm{~cm}, 15.3 \mathrm{~cm}$ wide) is located near the waist area (about $10 \mathrm{~cm}$ above the belt part) (Figure 1). Additionally, in order to avoid the influence of liquids such as water used by fire extinguishing activity etc., the accelerometer was covered with vinyl material and fixed onto the chest pocket with adhesive tape.

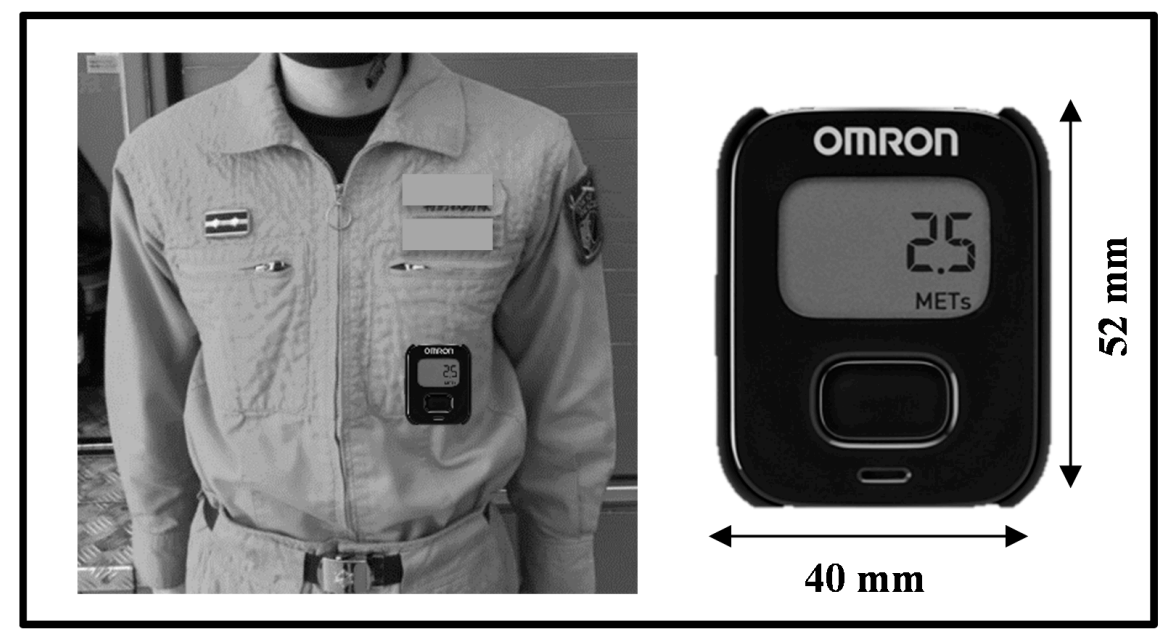

Figure 1. Placement of to wear a tri-axial accelerometer (Omron activity meter, Active style PRO HJA-750C $-23 \mathrm{~g}, 40 \times 52 \times 12 \mathrm{~mm}$; Omron Healthcare Co., Ltd. Kyoto, Japan). The base part of the chest pocket (length-16.2 cm, width-15.3 cm) is located near the waist area (about $10 \mathrm{~cm}$ above the belt part). 
Table 1. Activity group and job rank of participants by each disaster simulation training.

\begin{tabular}{|c|c|c|c|c|c|c|}
\hline & & Rescue & Fire-Fighting & EMS * & Other ** & Subtotal \\
\hline \multirow{6}{*}{$\begin{array}{l}\text { Training A } \\
\text { (Oct. 2016) }\end{array}$} & Fire Captain & 6 & 0 & 0 & 1 & 7 \\
\hline & Fire Lieutenant & 11 & 3 & 4 & 2 & 20 \\
\hline & Fire Sergeant & 11 & 3 & 2 & 1 & 17 \\
\hline & Assistant Fire Sergeant & 5 & 3 & 1 & 0 & 9 \\
\hline & Firefighter & 6 & 1 & 2 & 0 & 9 \\
\hline & Subtotal & 39 & 10 & 9 & 4 & 62 \\
\hline \multirow{6}{*}{$\begin{array}{l}\text { Training B } \\
\text { (Mar. 2017) }\end{array}$} & Fire Captain & 2 & - & 0 & 2 & 4 \\
\hline & Fire Lieutenant & 17 & - & 1 & 5 & 23 \\
\hline & Fire Sergeant & 3 & - & 0 & 0 & 3 \\
\hline & Assistant Fire Sergeant & 0 & - & 0 & 0 & 0 \\
\hline & Firefighter & 0 & - & 0 & 0 & 0 \\
\hline & Subtotal & 22 & - & 1 & 7 & 30 \\
\hline \multirow{6}{*}{$\begin{array}{l}\text { Training C } \\
\text { (Oct. 2017) }\end{array}$} & Fire Captain & 6 & $2(1)^{+}$ & 0 & 1 & 8 \\
\hline & Fire Lieutenant & 10 & 2 & 2 & 1 & 15 \\
\hline & Fire Sergeant & 16 & 3 & 3 & 1 & 23 \\
\hline & Assistant Fire Sergeant & 1 & 0 & 2 & 0 & 3 \\
\hline & Firefighter & 7 & 3 & 2 & 0 & 12 \\
\hline & Subtotal & 40 & 9 & 9 & 3 & 61 \\
\hline \multirow{6}{*}{$\begin{array}{l}\text { Training D } \\
\text { (Mar. 2018) }\end{array}$} & Fire Captain & 0 & 0 & 0 & 1 & 1 \\
\hline & Fire Lieutenant & 17 & 0 & 0 & 6 & 23 \\
\hline & Fire Sergeant & 4 & 0 & 0 & 0 & 4 \\
\hline & Assistant Fire Sergeant & 0 & 0 & 0 & 0 & 0 \\
\hline & Firefighter & 0 & 0 & 0 & 0 & 0 \\
\hline & Subtotal & 21 & 0 & 0 & 7 & 28 \\
\hline \multirow{8}{*}{$\begin{array}{l}\text { Training E } \\
\text { (Nov. 2018) }\end{array}$} & Fire Captain & 3 & 0 & 0 & 1 & 4 \\
\hline & Fire Lieutenant & 10 & 3 & 3 & 2 & 18 \\
\hline & Fire Sergeant & 12 & 3 & 2 & 2 & 19 \\
\hline & Assistant Fire Sergeant & 6 & 1 & 4 & 0 & 11 \\
\hline & Firefighter & 5 & 2 & 0 & 0 & 7 \\
\hline & Subtotal & 36 & 9 & 9 & 5 & 59 \\
\hline & Subtotal $* * *$ & $\begin{array}{c}158 \\
(66 \%)\end{array}$ & $\begin{array}{c}28 \\
(12 \%)\end{array}$ & $\begin{array}{c}28 \\
(12 \%)\end{array}$ & $\begin{array}{c}26 \\
(11 \%)\end{array}$ & \\
\hline & Total & & & 240 & & \\
\hline
\end{tabular}

Activity groups are organized rescue, firefighting, Emergency medical service (EMS) and the other teams (the command and back up unit). Each officer is classified by job rank (Fire captain, Fire Lieutenant, Fire Sergeant, Assistant Fire Sergeant, and Fire Fighter). * EMS = Emergency medical service ${ }^{* *}$ Other $=$ Command and back up unit ${ }^{* * *}$ Subtotal $=$ Each activity group. ${ }^{\dagger}$ One (1) participant withdrew from the study due to mechanical trouble.

\subsection{Data Processing Algorithm}

Accelerometers (Active style Pro HJA-750C, Omron Healthcare Co., Ltd. Kyoto, Japan) were programmed to save activity data once per $10 \mathrm{sec}$, which resulted in data files totaling 8640 data points each day. With a measurement frequency of $32 \mathrm{~Hz}$, it is possible to record at epoch length of $10 \mathrm{~s}$ value. It records acceleration information on three axes in the longitudinal direction ( $\mathrm{x}$ axis) and the lateral direction ( $\mathrm{y}$ axis) vertical direction ( $\mathrm{z}$ axis) and calculates the resultant acceleration. The dynamic range showing the ratio between the minimum value and the maximum value of identifiable signals is $3 \mathrm{mG}$ to $6 \mathrm{G}$. It is also possible to capture correct physical activity such as a change in body movement and posture. In addition, it can record high intensity physical activity more accurately than walking [17]. Time interval for recording the acceleration (epoch length) is $60 \mathrm{~s}$, which has been widely used [19], and has also been recommended for a shorter time of recording [20].

Devices capable of measuring in a shorter time have been developed, and the validity of the physical activity evaluation of the epoch length value for $10 \mathrm{~s}$ has been shown [19]. For that reason, we selected equipment that can measure every $10 \mathrm{~s}$. The data was recorded at each $10 \mathrm{~s}$ data point, and it was transformed into METs (i.e., metabolic equivalent) using 
Omron's algorism [17,21]. Next, each transformed data point was converted to units of AEE (Activity Energy Expenditure), $\mathrm{kcal} \mathrm{min} / 10 \mathrm{~s}[17,21]$. The algorithm embedded in Omron's equipment is said to display $24 \mathrm{~h}$ from 0:00 to $24: 00$ as the daily energy expenditure. However, in the disaster simulation training, participants performed the rescue activity from 11:00 to 11:00 the next day, so we calculated from 11:00 to 11:00 as one day.

\subsection{Activity Log}

The activity log of the research was recorded by filling the survey form distributed to the research participants. They recorded their activity log every $30 \mathrm{~min}$. The participants were asked to describe their activities in the activity log. Because the Tri-axial Accelerometer only shows the intensity, we asked each participant to write down what kind of activity they actually did.

\subsection{Analysis}

All data were analyzed using windows software SPSS (version 24). Descriptive statistics (mean \pm standard deviation (SD)) were initially calculated for all measured variables. One-way analysis of variance was used for mean-to-mean significance testing, and Tukey's HSD method was used for multiple comparisons.

\section{Results}

\subsection{Participants, Location and Weather Condition}

A total of 241 participants joined the study; however, one participant withdrew from the study due to technical issues with the accelerometer, and thus data from 240 participants was collected and analyzed in this study $(\mathrm{n}=240)$ (Table 1$)$. All trainings were held $24 \mathrm{~h}$ a day from the morning to the next morning in the Kanto region of Japan. Rainfall affected their activity during training $A, B$ and $C$. In the A session, some training was interrupted due to rainfall (Appendix A).

\subsection{Total Energy Expenditure (TEE)}

The average of the total survey training TEE is about $3619( \pm 499) \mathrm{kcal}$. A comparison with activity group is shown in Figure 2. The TEE of the rescue team had an average of $3707( \pm 491) \mathrm{kcal}$, the average of the fire-fighting team was $3290( \pm 342) \mathrm{kcal}$, the EMS team had an average of $3308( \pm 318) \mathrm{kcal}$, and the other teams had $3774( \pm 575) \mathrm{kcal}$. The average energy expenditure was the highest for the other teams and the lowest for fire-fighting team. The TEE of the rescue team and the other teams were significantly higher $(p<0.05)$ than the fire-fighting team and EMS team.

Comparison by job rank is shown in Figure 3. TEE of the Fire Captain is $3329( \pm 272) \mathrm{kcal}$ on average, $3692( \pm 573) \mathrm{kcal}$ on average for the Fire Lieutenant, $3691( \pm 482) \mathrm{kcal}$ on average for the Fire Sergeant, and $3489( \pm 386) \mathrm{kcal}$ on average for the Assistant Fire Sergeant. The average was $3546( \pm 378) \mathrm{kcal}$ for the Fire-Fighter. The average energy expenditure was the highest for the Fire Lieutenant and lowest for the Fire Captain. TEE of the Fire Captain was significantly lower $(p<0.05)$ than the Fire Lieutenant and Fire Sergeant.

\subsection{Intensity of Activity}

The intensity of activity was classified into SED, LPA and MPA+VPA by each activity group. Similar to previous studies, the intensity of activity was determined by activity count cut points for sedentary (SED; >1.49 METs), light (LPA; >1.5-2.99 METs), moderate (MPA; >3.0-5.99 METs) and vigorous-intensity physical activity (VPA; >6 METs) [22]. The mean percent of time spent in each intensity category included: sedentary (39\%), light $(44.5 \%)$, and moderate/vigorous (16.5\%) (Table 2). The average nap time according to life records was 4:20:10, while the longest was 5:05:21 for fire-fighters, and the shortest was 3:12:38 for the other teams. 


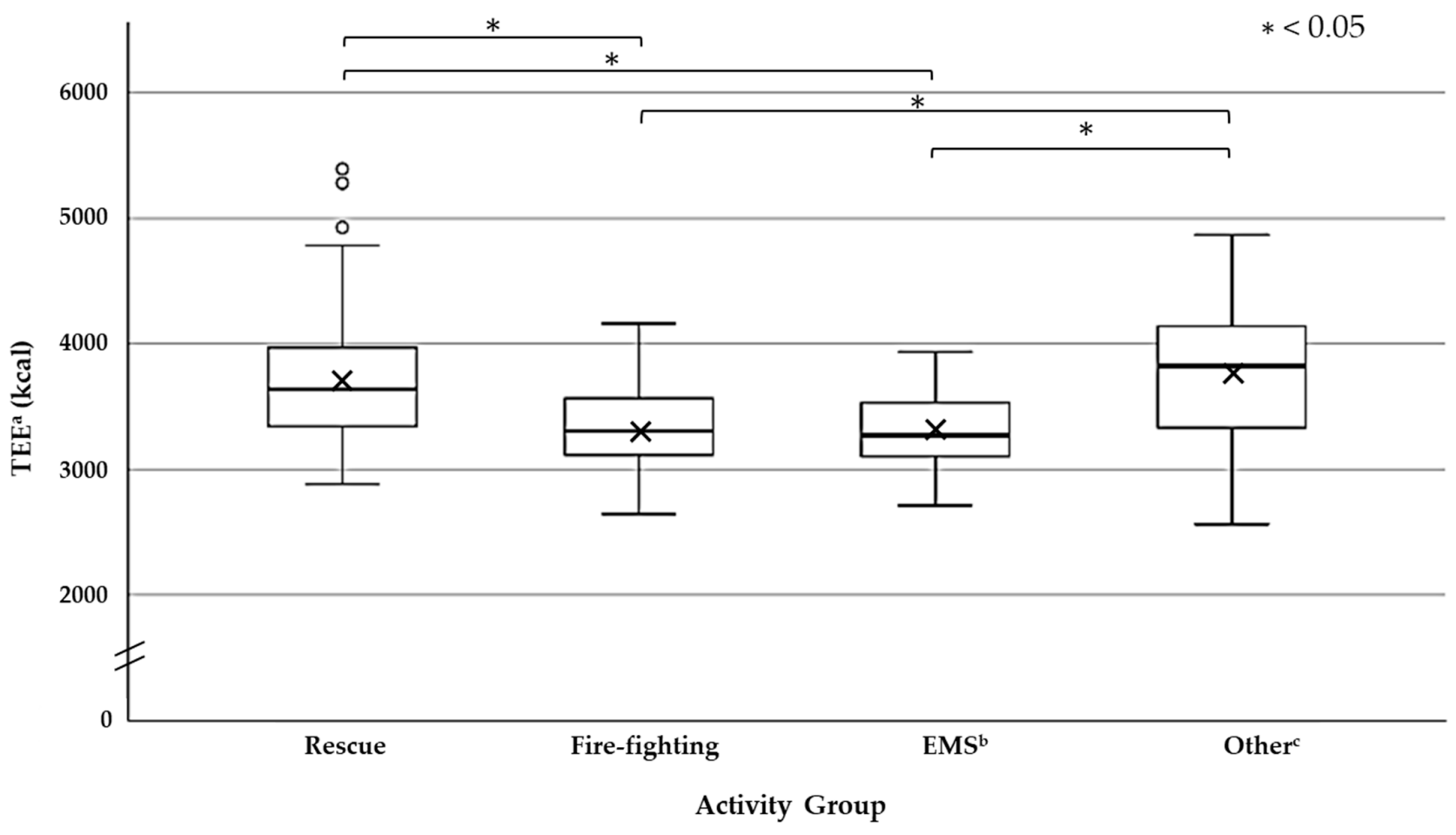

Figure 2. Total energy expenditure (TEE) of each disaster response Activity Group ( $24 \mathrm{~h}$ from arrival at the disaster site to the end of the disaster response activity during the two days of activity training). The TEE of the Rescue team and the other team * indicates significant (One-way analysis of variance and Tukey's HSD method: $p<0.05$ ) higher than the TEE of the Fire-Fighting team and the EMS team. $\times$ shows the average of each activity group in the box plot. $\circ$ shows the outlier. $\mathrm{a}, \mathrm{TEE}=$ Total energy expenditure, ${ }^{\mathrm{b}}$, EMS $=$ Emergency medical service, ${ }^{2}{ }^{\mathrm{c}}$, Other $=$ Command and back up unit.

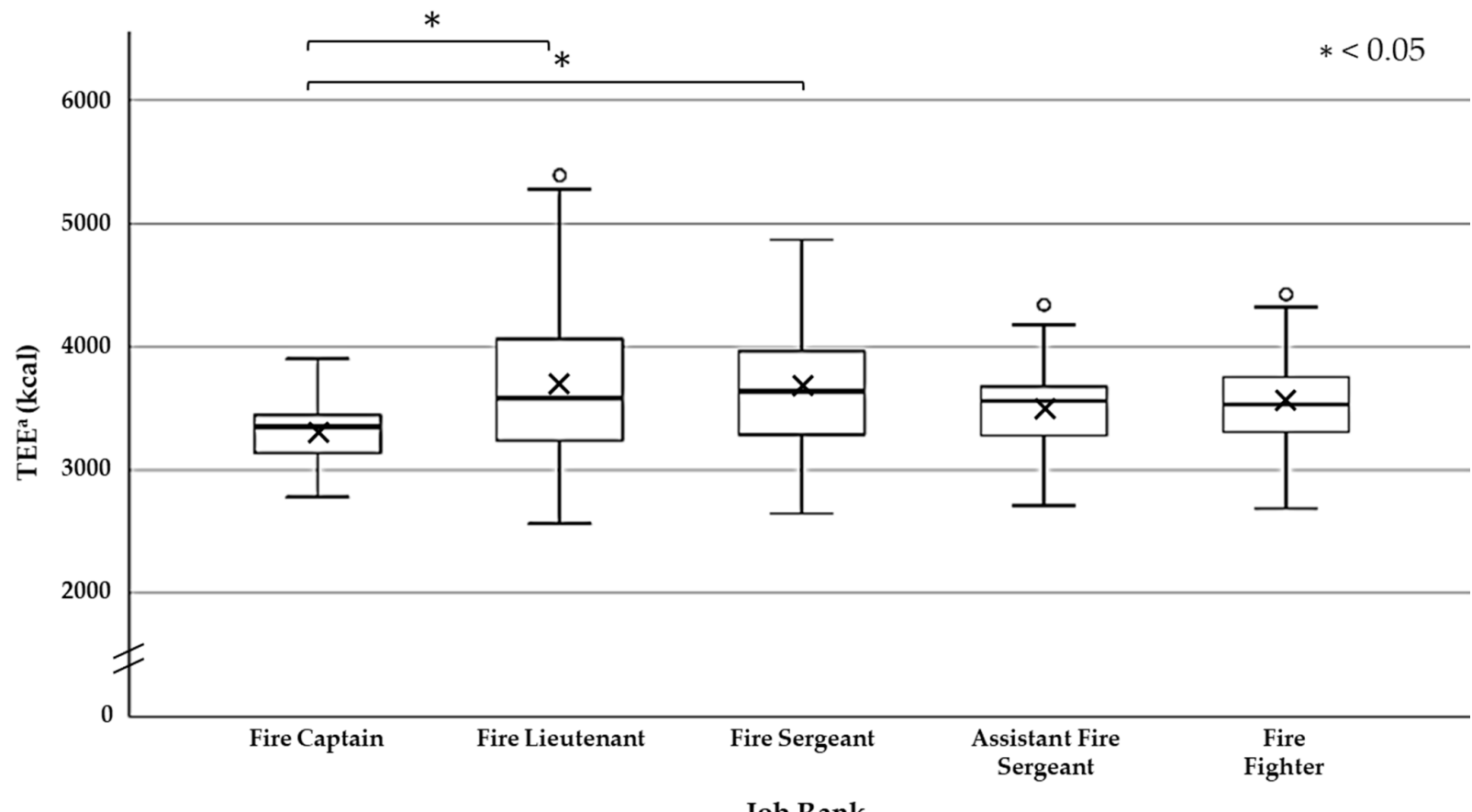

Figure 3. Total energy expenditure (TEE) of each Job Rank ( $24 \mathrm{~h}$ from arrival at the disaster site to the end of the disaster response activity during the two days of activity training). The TEE of the Fire Captain * indicates significant (One-way analysis of variance and Tukey's HSD method: $p<0.05$ ) lower than the TEE of the Fire Lieutenant and the Fire Sergeant. $\times$ shows the average of each activity group in the box plot. $\circ$ shows the outlier. ${ }^{\text {a }}$ TEE $=$ Total energy expenditure. 
Table 2. Intensity of activity Group and Average nap time.

\begin{tabular}{|c|c|c|c|c|c|c|c|c|c|c|c|}
\hline & & \multicolumn{2}{|c|}{ ALL } & \multicolumn{2}{|c|}{ Rescue } & \multicolumn{2}{|c|}{ Fire-Fighting } & \multicolumn{2}{|c|}{ EMS * } & \multicolumn{2}{|c|}{ Other ${ }^{* *}$} \\
\hline \multicolumn{2}{|c|}{ SED } & \multicolumn{2}{|c|}{$39.0 \%$} & $37.8 \%$ & $\mathrm{C}$ & $40.5 \%$ & $\mathrm{CD}$ & $48.7 \%$ & $\mathrm{ABD}$ & $34.7 \%$ & $\mathrm{BC}$ \\
\hline \multicolumn{2}{|c|}{ LPA } & \multicolumn{2}{|c|}{$44.5 \%$} & $44.5 \%$ & C & $46.9 \%$ & $\mathrm{C}$ & $40.4 \%$ & $\mathrm{ABD}$ & $46.6 \%$ & $\mathrm{C}$ \\
\hline \multicolumn{2}{|c|}{$\mathrm{MPA}+\mathrm{VPA}$} & \multicolumn{2}{|c|}{$16.5 \%$} & $17.8 \%$ & $\mathrm{BC}$ & $12.6 \%$ & $\mathrm{AD}$ & $10.9 \%$ & $\mathrm{AD}$ & $18.7 \%$ & $\mathrm{BC}$ \\
\hline \multirow{2}{*}{$\begin{array}{c}\text { Average } \\
\text { nap time } \\
\text { (SD) }\end{array}$} & $\mathrm{MIN}^{* * *}$ & \multirow{2}{*}{$\begin{array}{c}4: 20: 10 \\
( \pm 1: 35: 11)\end{array}$} & 1:00:00 & 4:21:36 & 1:30:00 & \multirow{2}{*}{$\begin{array}{c}5: 05: 21 \\
( \pm 1: 33: 07)\end{array}$} & $3: 30: 00$ & \multirow{2}{*}{$\begin{array}{c}4: 12: 52 \\
( \pm 1: 00: 12)\end{array}$} & $2: 30: 10$ & \multirow{2}{*}{$\begin{array}{c}3: 12: 38 \\
( \pm 1: 10: 12)\end{array}$} & 1:00:00 \\
\hline & $\operatorname{MAX}^{* * *}$ & & $7: 30: 00$ & $( \pm 1: 38: 51)$ & 7:30:00 & & 7:30:00 & & 5:30:00 & & 5:00:00 \\
\hline
\end{tabular}

A: significant $(p<0.05)$ for Rescue; B: significant $(p<0.05)$ for Firefighting; C: significant $(p<0.05)$ for EMS; D: significant $(p<0.05)$ for Other. The intensity of activity Group was classified into SED, LPA and MPA+VPA by each activity group (activity count cut points for sedentary (SED; >1.49 METs), light (LPA; >1.5-2.99 METs), moderate (MPA; >3.0-5.99 METs), and vigorous-intensity physical activity (VPA; $>6$ METs)). A, B, C and D* indicate significant (One-way analysis of variance and Tukey's HSD method: $p<0.05$ ). Average nap time is according to the life records. ${ }^{*}$ EMS $=$ Emergency medical service ${ }^{* *}$ Other $=$ Command and back up unit. ${ }^{* *}$ MIN and MAX are expressed as (hh: mm: ss).

\section{Discussion}

Our study provides new insight into energy expenditure of a large-scale disaster training targeting a large sample size of fire-fighters belonging to multiple occupations and job ranks using the tri-axial accelerometer measurement method. The limitation that had until now prevented field studies of rural fire-fighters was the logistical difficulty and cost [10]. Substantial research has been carried out in laboratories where urban fire conditions were simulated [23]. However, rural fire conditions cannot be easily and realistically simulated in the laboratory, as the associated variables, such as the size of the area, terrain and meteorological conditions are numerous [15]. Although there are previous studies targeting forest fires, rural fires and urban fires, there are few studies targeting multiple disasters [11-13]. Large-scale disasters in Japan often cover wide areas, including urban areas, mountainous areas and coastal areas. The large-scale disaster response training in this study is a complex disaster activity, which includes both forest fires and urban fires.

Fire-fighting is an intensive activity, and requires high energy (food) and physical activity. It has been reported that firefighters have felt unwell/or are having discomfort at the time of a large-scale disaster; the same has been mentioned by the fire-fighters. There is a shortage of supplies immediately after the disaster [2]. In addition, Koizumi et al. (2017) have previously reported on an insufficient preparation during a survey of fire departments nationwide, and there were voices calling for standards [4], so it was necessary to indicate the actual required amount (food in particular) by the firefighters. One approach is to estimate the energy requirements/expenditure. Although there are a few surveys on the amount of energy expenditure for regular fire-fighting work, there is no study that estimates energy expenditure during a large-scale disaster. Moreover, the energy expenditure value/data remains unclear, and thus it becomes important to first estimate the energy expenditure through a scientific study. Additionally, fire brigades are varied with different responsibilities depending on the position, which is necessary in order to clarify the command system [6]. So, we considered that the difference in energy expenditure may be related to the job type and job class. This research targets activity in large-scale disasters, and it is the primary purpose of firefighters in a large-scale disaster is to save lives, thus the TEE was determined. Moreover, as the types and tasks of rescue activities are complex and diverse, different work types were examined.

The average of TEE is about $3619( \pm 499)$ kcal. Previously, the average TEE values were reported $3626 \mathrm{kcal} /$ day for a fire-fighter [11], $4878 \mathrm{kcal} /$ day for a wildland fire-fighter [12], and $4009 \mathrm{kcal} /$ day for an urban fire-fighter [13] using the DLW method. The AC method reported $4716 \mathrm{kcal} /$ day for a wildland fire-fighter [10] and $2531 \mathrm{kcal} /$ day for an urban fire-fighter [13]. In addition, as another activity field, average TEE values of professional athletes during the soccer game season were reported to be about $3532 \pm 408 \mathrm{kcal} /$ day [24]. In order to investigate a large number of subjects at the same time in a training that seems to be close to a real disaster, we conducted a survey using a terminal whose accuracy was 
confirmed in a survey comparing the accuracy of wearable devices with the chamber and DLW method [25]. However, the following underestimation is also possible for AC method. In the Touno et al. [13] study, there is also a report that there is a $33 \%$ difference between the AC method and the DLW method.

The rescue team and the other teams were found to be significantly higher with regards to the TEE than that of the firefighting team and the EMS team. The rescue team is specialized in life saving activities, and especially in the case of a large-scale disaster, it is necessary to find and rescue a person in need of removal various obstacles. Therefore, it was clear that the amount of energy expenditure had increased as the contents of activities are diverse. In addition, it may be that the energy expenditure increased because the other teams had been working for a long time, while accepting the fire-fighters without rest at the base. The others team has the shortest nap time. Robertson et al. (2017) [16] surveyed TEE for the crews performing base operations and reported a TEE of $2842 \pm 649.9 \mathrm{kcal}$, which is lower than the fire-fighters $4538 \pm 106.3 \mathrm{kcal}$. In the survey by Robertson et al. [16], base operations are considered to be activities that are performed when Fire Rangers are not working on fire response activities, but are reporting daily to the Fire Management Headquarters (FMH), so there may be differences with activities in this study. Touno et al. reported that the TEE of the rescue team during normal work was estimated to be $2531 \pm 186 \mathrm{kcal} / \mathrm{d}$ by AC [13]. Fire fighters in the current research are considered to consume more energy than rescue teams during normal work; i.e., higher than the results obtained by Touno et al. [13]. Fire-fighting teams and EMS teams are considered to consume less energy than rescue teams and other teams. This is because the frequency of use of equipment and vehicles is high, and it is considered that standby time and nap time are longer.

Although there are previous researches that have surveyed and reported by the roles of the fire brigade personnel [16], there are few studies that have reported by job rank. Research into physiological responses during fire-fighting activities is reliant on data collected during simulations of live fires performed in facilities that are used to train newly recruited firefighters [26]. Fire-fighting personnel engage in dangerous operations such as fire suppression and life-saving at sites such as fires. In order to conduct efficient firefighting activities and ensure the safety of the staff, a system with a solid command and control system is required. In order to establish the command and command system of such fire brigade staff, unit formation under the class system is performed [27]. Therefore, it is possible that the content of the activity differs depending on the rank, and the energy expenditure also changes accordingly. In this research, since the fire Captain is responsible for instructing members, it can be assumed that they experience lower energy expenditure than the fire Lieutenant and the fire Sergeant. Among the members, the energy expenditure of the fire Captain and the fire Lieutenant was high because they thought that they carried out the activities themselves while giving their command to the subordinates, the activity time was long, and the activity contents were diverse.

Cuddy reported that Wildland fire-fighters spent $49 \pm 8 \%, 39 \pm 6 \%$, and $12 \pm 2 \%$ in the SED, LPA and MPA/VPA categories, respectively [28]. In this study, EMS teams spent $48.7 \%, 40.4 \%$ and $10.9 \%$ in the SED, LPA and MPA/VPA categories, similar to Cuddy's report. The SED and LPA of EMS teams were found to be significantly larger than the rescue team, firefighting team and the other teams. In addition, EMS teams were on standby while the rescue team and firefighting team searched and transported the rescuers. The other teams have the shortest nap time and the lowest SED rate. The other teams do not have direct disaster activities, but support activities of the rescue team, firefighting team, and EMS team at any time, resulting in a low SED rate. The rescue team carried the equipment, climbing and searching for rescuers, excavating the shovel, and transporting the sand and equipment. Because there was a significant difference in the types of activities, it was considered necessary to examine the contents of each activity group when considering active foods and supplementary foods in the future. 
This research also highlighted some limitations, and these are mentioned below:

(a) Load by equipment: At the time of disaster activity a variety of equipment is necessary, so the load by the carrying items is added. For rescue and fire-fighters, a load of $25 \mathrm{~kg}$ was calculated with all attached, including respiratory equipment and EMS was estimated to have a load of $4 \mathrm{~kg}$. It has been reported that energy expenditure and exercise intensity increase with load [29]. Energy expenditure is expected to increase due to the load of the items to be carried, but the increase in energy expenditure of this load cannot be measured by the AC method.

(b) Fire-fighting specific actions: Accelerometers generate their output in form of "counts" per unit time [30]. In order for the accelerometer to recognize the activity, it is necessary to count, but the disaster operation includes many activities that are not counted such as maintaining the load state, activities bending the body in a collapsed building, etc. In the future, it will be necessary to add a method for measuring such activities.

(c) Inactivity for training: It is probable that the activities were limited because this study was training. Disaster assumptions end after a certain amount of time, because the activity of trainings is planned and limited. In an actual disaster, the priority is saving human life, so the amount of activity may increase compared to training. The influence of the weather is one of them. It rained during training A, B and C. In training $\mathrm{A}$, a part of training was interrupted due to rain, but in training $\mathrm{B}$ and $\mathrm{C}$ activity continued without interruption. Since it was equivalent weather conditions, it is expected that continuation could be possible even in training A. Particularly in emergency situations in the case of large-scale disasters, this rainfall amount $(0.5 \mathrm{~mL} / \mathrm{h})$ is likely to continue activity. However, if the risk of secondary disasters is considered due to weather conditions such as sediment-related disasters caused by heavy rain, there is also the possibility of deciding to reduce the activity scale. In disaster activities, while paying attention to the safety of the crew members, they are engaged in activities with the highest priority to human life, so if the risk of secondary disasters and the possibility of danger to the crew members are low, the activities will continue even if it is raining. From the above, it seems that the interruption of rain activity in this research is an interruption because it was training. This leads to an underestimation of energy expenditure in actual disasters. In this view, there was no energy expenditure by physical activity that activity originally should take place from 15:30 to 17:00, where activity was interrupted by rain in training A. In training $\mathrm{A}$, activity was interrupted for $1 \mathrm{~h}$ and $30 \mathrm{~min}$. In addition, since rest and nap were reliably given because it was training, it is considered that energy expenditure was lower because the activity time was limited than the actual disaster activity. From the above, the results of this study, which can be measured with a 3-axis accelerometer, seem to show the lowest energy expenditure during disaster activities.

(d) The number of participants and diversity of situations: The number of participants and diversity of situations were limited. It is possible that there is also a bias in the season in which the target training was conducted.

\section{Conclusions}

As a result of investigating the 5 trainings and 240 subjects using the AC method that can calculate energy expenditure of fire-fighters (disaster response team) in large-scale disaster activity training, an average TEE of $3619( \pm 499) \mathrm{kcal} / 24 \mathrm{~h}$ was determined. As an activity group, rescue teams and other teams have high energy expenditure. In the job rank, the Fire Lieutenant has high energy expenditure. Due to load, fire-fighting specific actions and activity limitations for training, the underestimation by the AC method could be considered in the future. 
Author Contributions: Conceptualization, N.K.; Data curation, N.K.; Formal analysis, N.K., Y.N., H.O. and N.O.; Funding acquisition, N.K. and N.O.; Investigation, N.K., Y.N., H.O. and N.O.; Methodology, N.K., Y.N., H.O. and N.O.; Project administration, N.O.; Supervision, N.O.; Writingoriginal draft, N.K.; Writing-review and editing, N.K., Y.N., H.O., R.R. and N.O. All authors have read and agreed to the published version of the manuscript.

Funding: Funding from the Advanced Research Initiative for Human High Performance (ARIHHP), University of Tsukuba) is gratefully acknowledged (2016(I)12, 2017(I)10, 2018(I)4, 2019(I)6,2020(I)3).

Institutional Review Board Statement: The study was conducted according to the guidelines of the Declaration of Helsinki, and approved by the University of Tsukuba Physical Education Research Ethics Committee (Number: T28-66, Study on the activity and nutrition of Fire service in disaster response, approved 3 October 2016).

Informed Consent Statement: Informed consent was obtained from all subjects involved in the study.

Data Availability Statement: The data presented in this study are available on request from the corresponding author.

Acknowledgments: We are extremely grateful to all the fire-fighters who cooperated with our research.

Conflicts of Interest: The authors declare no conflict of interest.

\section{Appendix A}

Table A1. Overview of Disaster simulation training (Long-term training conducted with assumptions that are close to real disasters and whose contents are not informed to participating members in advance, which is considered to be the most similar to a real disaster).

\begin{tabular}{|c|c|c|c|c|c|}
\hline & \multirow{2}{*}{ Disaster Situation } & $\begin{array}{l}\text { Assumption } \\
\text { Area }\end{array}$ & Precipitation (mm) & \multirow{2}{*}{ Training Activity } & \multirow{2}{*}{$\begin{array}{c}\text { Training } \\
\text { Participants }\end{array}$} \\
\hline & & Location & $\begin{array}{c}\text { Average } \\
\text { Temperature }\left({ }^{\circ} \mathrm{C}\right)\end{array}$ & & \\
\hline \multirow{11}{*}{ A } & \multirow{11}{*}{$\begin{array}{l}\text { In October 2016, an epicenter } \\
\text { earthquake (foreshock) with a } \\
\text { seismic intensity of } 5 \text { struck the } \\
\text { southern part of Tochigi } \\
\text { prefecture, and Mt. Nasu } \\
\text { erupted. Many climbers were } \\
\text { injured in Mt. Nasu due to this } \\
\text { disaster. Around 9:30, a direct } \\
\text { earthquake with seismic } \\
\text { intensity of } 6 \text { occurred in the } \\
\text { southern part of Tochigi } \\
\text { prefecture (main shock), } \\
\text { causing serious damage in } \\
\text { municipalities in the southern } \\
\text { part of the prefecture }\end{array}$} & \multirow{4}{*}{$\begin{array}{l}\text { Mountainous } \\
\text { area }\end{array}$} & \multirow{6}{*}{8.5} & $\begin{array}{l}\text { High-rise buildings: High angle } \\
\text { rescue, elevator rescue }\end{array}$ & \multirow{11}{*}{$\begin{array}{l}\text { Approximately, } \\
1000 \text { from } 63,550 \\
\text { fire-fighters }\end{array}$} \\
\hline & & & & Large-scale fire & \\
\hline & & & & Hazardous material rescue & \\
\hline & & & & $\begin{array}{l}\text { River flooding and bridge } \\
\text { collapse training }\end{array}$ & \\
\hline & & \multirow{2}{*}{ City area } & & Landslide rescue & \\
\hline & & & & $\begin{array}{l}\text { Poisonous and deleterious } \\
\text { substances rescue }\end{array}$ & \\
\hline & & \multirow{5}{*}{$\begin{array}{l}\text { Tochigi- } \\
\text { prefecture }\end{array}$} & \multirow{5}{*}{15.3} & Volcanic eruption rescue & \\
\hline & & & & Vehicle rescue, multiple pileup rescue & \\
\hline & & & & $\begin{array}{l}\text { Structural collapse, trench rescue, } \\
\text { machinery entrapment }\end{array}$ & \\
\hline & & & & Logistics support training & \\
\hline & & & & Fuel supply training & \\
\hline
\end{tabular}


Table A1. Cont.

\begin{tabular}{|c|c|c|c|c|c|}
\hline & \multirow{2}{*}{ Disaster Situation } & $\begin{array}{l}\text { Assumption } \\
\text { Area }\end{array}$ & Precipitation $(\mathrm{mm})$ & \multirow{2}{*}{ Training Activity } & \multirow{2}{*}{$\begin{array}{c}\text { Training } \\
\text { Participants }\end{array}$} \\
\hline & & Location & $\begin{array}{c}\text { Average } \\
\text { Temperature }\left({ }^{\circ} \mathrm{C}\right)\end{array}$ & & \\
\hline \multirow{14}{*}{ B } & \multirow{14}{*}{$\begin{array}{l}\text { In March 2017, due to the } \\
\text { occurrence of a large } \\
\text { earthquake, the local } \\
\text { government of the disaster area } \\
\text { requested the Japanese } \\
\text { government to send a Japan } \\
\text { Disaster Rescue (JDR) team. } \\
\text { JDR gathered at Narita } \\
\text { International Airport and was } \\
\text { dispatched to the afflicted area. } \\
\text { The disaster assumption was } \\
\text { made for } 24 \text { h in the developing } \\
\text { countries, where they are } \\
\text { dispatched }\end{array}$} & \multirow{6}{*}{$\begin{array}{l}\text { Developing } \\
\text { foreign country }\end{array}$} & \multirow{6}{*}{1} & Convocation training & \multirow{14}{*}{$\begin{array}{l}\text { Approximately, } \\
70 \text { from } 10,200 \\
\text { fire-fighters }\end{array}$} \\
\hline & & & & Immigration training & \\
\hline & & & & $\begin{array}{l}\text { Establish and control a Base of } \\
\text { Operations (BoO) }\end{array}$ & \\
\hline & & & & Activation and mobilisation training & \\
\hline & & & & $\begin{array}{l}\text { Gross and technical decontamination } \\
\text { in any environment required }\end{array}$ & \\
\hline & & & & Disaster assumption (9 situations) & \\
\hline & & \multirow{8}{*}{ Osaka-prefecture } & \multirow{8}{*}{9} & Collapse rescue & \\
\hline & & & & Confined space rescue & \\
\hline & & & & Trench/cave-in rescue & \\
\hline & & & & Obstacle removal & \\
\hline & & & & Rope rescue & \\
\hline & & & & Confined space rescue & \\
\hline & & & & Landslide rescue & \\
\hline & & & & Rope rescue & \\
\hline \multirow{10}{*}{$\mathrm{C}$} & \multirow{10}{*}{$\begin{array}{l}\text { In October } 2017 \text {, an earthquake } \\
\text { with a maximum seismic } \\
\text { intensity of } 6 \text { occurred in the } \\
\text { southern part of Gunma } \\
\text { Prefecture (Ota Fault). Due to } \\
\text { the earthquake, buildings } \\
\text { collapsed sediment-related } \\
\text { disasters, fire, road damage, } \\
\text { etc., occurred in Gunma } \\
\text { prefecture, causing serious } \\
\text { damage. Governor of Gunma } \\
\text { Prefecture requested the } \\
\text { Commissioner of the Fire and } \\
\text { Disaster Management Agency } \\
\text { to deploy the Emergency Fire } \\
\text { Response team }\end{array}$} & \multirow{5}{*}{$\begin{array}{l}\text { Inland area with } \\
\text { a fault }\end{array}$} & \multirow{5}{*}{0.5} & $\begin{array}{l}\text { Structural collapse, trench rescue, } \\
\text { machinery entrapment. }\end{array}$ & \multirow{10}{*}{$\begin{array}{l}\text { Approximately, } \\
1000 \text { from } 63,550 \\
\text { fire-fighters }\end{array}$} \\
\hline & & & & Collapse of bridges rescue & \\
\hline & & & & Vehicle rescue, multiple pileup rescue & \\
\hline & & & & Landslide rescue & \\
\hline & & & & Tunnel collapse rescue & \\
\hline & & \multirow{5}{*}{$\begin{array}{l}\text { Gunma- } \\
\text { prefecture }\end{array}$} & \multirow{5}{*}{13.0} & $\begin{array}{l}\text { Derailment rescue (a large number of } \\
\text { sick and wounded) }\end{array}$ & \\
\hline & & & & Large-scale fire rescue & \\
\hline & & & & $\begin{array}{l}\text { Poisonous and deleterious } \\
\text { substances rescue }\end{array}$ & \\
\hline & & & & Basement operation training & \\
\hline & & & & Fuel supply training & \\
\hline \multirow{10}{*}{$\mathrm{D}$} & \multirow{10}{*}{$\begin{array}{l}\text { In March 2018, due to the } \\
\text { occurrence of a large } \\
\text { earthquake, the local } \\
\text { government of the disaster area } \\
\text { requested the Japanese } \\
\text { government to send a Japan } \\
\text { Disaster Rescue (JDR) team. } \\
\text { JDR gathered at Narita } \\
\text { International Airport and was } \\
\text { dispatched to the afflicted area. } \\
\text { The disaster assumption was } \\
\text { made for } 24 \text { h in the developing } \\
\text { countries, where they are } \\
\text { dispatched }\end{array}$} & \multirow{5}{*}{$\begin{array}{l}\text { Developing } \\
\text { foreign country }\end{array}$} & \multirow{5}{*}{9} & Convocation training & \multirow{10}{*}{$\begin{array}{l}\text { Approximately, } \\
70 \text { from } 10,200 \\
\text { fire-fighters }\end{array}$} \\
\hline & & & & Immigration training & \\
\hline & & & & Establish and control a BoO & \\
\hline & & & & Activation and mobilisation training & \\
\hline & & & & $\begin{array}{l}\text { Gross and technical decontamination } \\
\text { in any environment required }\end{array}$ & \\
\hline & & \multirow{5}{*}{ Osaka-prefecture } & \multirow{5}{*}{$\begin{array}{c}17.6 \\
8.6\end{array}$} & Disaster assumption (7 situations) & \\
\hline & & & & Collapse rescue (wooden structures) & \\
\hline & & & & $\begin{array}{l}\text { Collapse rescue } \\
\text { (reinforced concrete building) }\end{array}$ & \\
\hline & & & & Confined space rescue & \\
\hline & & & & Landslide rescue & \\
\hline
\end{tabular}


Table A1. Cont.

\begin{tabular}{|c|c|c|c|c|c|}
\hline & \multirow{2}{*}{ Disaster Situation } & $\begin{array}{l}\text { Assumption } \\
\text { Area }\end{array}$ & Precipitation (mm) & \multirow{2}{*}{ Training Activity } & \multirow{2}{*}{$\begin{array}{l}\text { Training } \\
\text { Participants }\end{array}$} \\
\hline & & Location & $\begin{array}{c}\text { Average } \\
\text { Temperature }\left({ }^{\circ} \mathrm{C}\right)\end{array}$ & & \\
\hline \multirow{14}{*}{$\mathrm{E}$} & \multirow{14}{*}{$\begin{array}{c}\text { In November 2018, an } \\
\text { earthquake with a maximum } \\
\text { seismic intensity of } 6 \text { occurred } \\
\text { in Kanagawa prefecture. Due to } \\
\text { this earthquake, several } \\
\text { buildings fell down, had fires, } \\
\text { road collapsed, and landslides } \\
\text { occurred. In the coastal area, a } \\
\text { large-scale industrial } \\
\text { fire occurred }\end{array}$} & \multirow{8}{*}{$\begin{array}{l}\text { Urban area, } \\
\text { Coastal area }\end{array}$} & \multirow{8}{*}{0} & Sediment disaster rescue & \multirow{14}{*}{$\begin{array}{l}\text { Approximately, } \\
1000 \text { from } 63,550 \\
\text { fire-fighters }\end{array}$} \\
\hline & & & & $\begin{array}{l}\text { Structural collapse, trench rescue, } \\
\text { machinery entrapment. }\end{array}$ & \\
\hline & & & & Vehicle rescue, multiple pileup rescue & \\
\hline & & & & Underground mall collapse rescue & \\
\hline & & & & $\begin{array}{l}\text { High-rise buildings: High angle } \\
\text { rescue, elevator rescue. }\end{array}$ & \\
\hline & & & & Large-scale fire rescue & \\
\hline & & & & Hazardous materials disaster rescue & \\
\hline & & & & Petrochemical complex fire rescue & \\
\hline & & \multirow{6}{*}{$\begin{array}{l}\text { Kanagawa- } \\
\text { prefecture }\end{array}$} & \multirow{6}{*}{$\begin{array}{c}18.3 \\
8.5\end{array}$} & $\begin{array}{l}\text { Subway accident rescue (a large } \\
\text { number of sick and wounded) }\end{array}$ & \\
\hline & & & & Sediment evacuation & \\
\hline & & & & Isolated village rescue & \\
\hline & & & & Tunnel collapse rescue & \\
\hline & & & & Bridge collapse training & \\
\hline & & & & Vehicle submersion rescue & \\
\hline
\end{tabular}

\section{References}

1. Coker, R.H.; Murphy, C.J.; Johannsen, M.; Galvin, G.; Ruby, B.C. Wildland firefighting adverse influence on indices of metabolic and cardiovascular health. J. Occup. Environ. Med. 2019, 61, 91-94. [CrossRef]

2. Akano, F.; Hosoya, M.; Genkai, T.; Yamaguchi, Y.; Ogata, H.; Omi, N. Study involving energy ration intake strategies for first-responder personnel when a major disaster occurs. Rep. Fire Technol. Saf. Labolatory 2013, 50, 70-77.

3. Fire and Disaster Management Agency. Survey Report on the Wide Area Activity Base of National Fire Service Team Training for Disaster Response. Available online: https://www.fdma.go.jp/pressrelease/houdou/items/h25/2504/250419_1houdou/250419 _1houdou_02_houdoushiryou.pdf (accessed on 8 June 2021).

4. Koizumi, N.; Akano, F.; Ogata, H.; Genkai, T.; Omi, N. Current status of food stockpiling for fire-fighters working in the disaster situation. J. Jpn. Disaster Food Soc. 2017, 4, 55-59.

5. Jhonson, B.V.B.; Mayer, J.M. Evaluating nutrient intake of career firefighters compared to military dietary reference ntakes. Nutrients 2020, 12, 876 .

6. Tokyo Fire Department. Available online: https://www.tfd.metro.tokyo.lg.jp/eng/ts/sa/firefighting.html (accessed on 31 July 2021).

7. Japan Institute of Country-ology and Engineering. Available online: http://www.jice.or.jp/knowledge/japan/commentary09 (accessed on 8 June 2021).

8. Fire and Disaster Management Agency. Activity Status of National Fire Service Team Training for Disaster Response in the 2011 Great East Japan Earthquake. Available online: https://www.fdma.go.jp/mission/prepare/rescue/items/h22_higasinihon.pdf (accessed on 9 June 2021).

9. Fire and Disaster Management Agency. Notification of Request for Cooperation Regarding Registration of National Fire Service Team Training for Disaster Response due to Change in Basic Plans for Organization and Facility Maintenance. Available online: https: / / www.fdma.go.jp/laws/tutatsu/assets/260305_ko26.pdf (accessed on 9 June 2021).

10. Heil, D.P. Estimating energy expenditure in wildland fire fighters using a physical activity monitor. Appl. Ergon. 2002, 33, 405-413. [CrossRef]

11. Livingstone, M.B.; Prentice, A.M.; Coward, W.A.; Ceesay, S.M.; Strain, J.J.; McKenna, P.G.; Nevin, G.B.; Barker, M.E.; Hickey, R.J. Simultaneous measurement of free-living energy expenditure by the doubly labeled water method and heart-rate monitoring. Am. J. Clin. Nutr. 1990, 52, 59-65. [CrossRef] [PubMed]

12. Ruby, B.; Shriver, T.; Zderic, T.; Sharkey, B.; Burks, C.; Tysk, S. Total energy expenditure during arduous wildfire suppression. Med. Sci. Sports Exerc. 2002, 34, 1048-1054. [CrossRef]

13. Touno, M.; Hasina, R.H.; Ebine, N.; Peng, H.; Yoshitake, Y.; Tanaka, H.; Saitoh, S. Measurement of total energy expenditure in Japanese Firefighters under normal working condition using the doubly labelled water method. Jpn. J. Phys. Fit Sports Med. 2003, $52,265-274$. 
14. Omi, N.; Ogata, H. Meals and refreshments for active performance on firefighters in large-scale disaster. Bull. Fac. Health Sport Sci. 2014, 37, 165-168.

15. Parker, R.; Vitalis, A.; Walker, R.; Riley, D.; Pearce, H.G. Measuring wildland fire fighter performance with wearable technology. Appl. Ergon. 2017, 59, 34-44. [CrossRef] [PubMed]

16. Robertson, A.H.; Larivière, C.; Leduc, C.R.; McGillis, Z.; Eger, T.; Godwin, A.; Larivière, M.; Dorman, S.C. Novel Tools in Determining the Physiological Demands and Nutritional Practices of Ontario Fire Rangers during Fire Deployments. PLoS ONE 2017, 12, e0169390. [CrossRef] [PubMed]

17. Ohkawara, K.; Oshima, Y.; Hikihara, Y.; Ishikawa-Takata, K.; Tabata, I.; Tanaka, S. Real-time estimation of daily physical activity intensity by a triaxial accelerometer and a gravity-removal classification algorithm. Br. J. Nutr. 2011, 105, 1681-1691. [CrossRef] [PubMed]

18. Hendelman, D.; Miller, K.; Baggett, C.; Debold, E.; Freedson, P. Validity of accelerometry for the assessment of moderate intensity physical activity in the field. Med. Sci. Sports Exerc. 2000, 32, S442-S449. [CrossRef] [PubMed]

19. Tanaka, C.; Tanaka, S. Role of epoch length on daily locomotive and non-locomotive physical activity using a triaxial accelerometer and relationships with obesity in adults. Jpn. J. Phys. Fit. Sports Med. 2013, 62, 71-78. [CrossRef]

20. Edwardson, C.L.; Gorely, T. Epoch length and its effect on physical activity intensity. Med. Sci. Sports Exerc. 2010, 42, 928-934. [CrossRef] [PubMed]

21. Oshima, Y.; Kawaguchi, K.; Tanaka, S.; Ohkawara, K.; Hikihara, Y.; Ishikawa-Takata, K.; Tabata, I. Classifying household and locomotive activities using a triaxial accelerometer. Gait Posture 2010, 31, 370-374. [CrossRef]

22. Chappel, S.; Aisbett, B.; Vincent, G.; Ridgers, N. Firefighters physical activity across multiple shifts of planned burn work. Int. J. Environ. Res. Public Health 2016, 13, 973. [CrossRef]

23. Bruce-Low, S.S.; Cotterrell, D.; Jones, G.E. Effect of wearing personal protective clothing and self-contained breathing apparatus on heart rate, temperature and oxygen consumption during stepping exercise and live fire training exercises. Ergonomics 2007, 50, 80-98. [CrossRef] [PubMed]

24. Ebine, N.; Rafamantanantsoa, H.H.; Nayuki, Y.; Yamanaka, K.; Tashima, K.; Ono, T.; Saitoh, S.; Jones, P.J. Measurement of total energy expenditure by the doubly labelled water method in professional soccer players. J. Sports Sci. 2002, 20, 391-397. [CrossRef]

25. Murakami, H.; Kawakami, R.; Nakae, S.; Yamada, Y.; Nakata, Y.; Ohkawara, K.; Sasai, H.; Ishikawa-Takata, K.; Tanaka, S.; Miyachi, M. Accuracy of 12 wearable devices for estimating physical activity energy expenditure using a metabolic chamber and the doubly labeled water method: Validation study. JMIR Mhealth Uhealth 2019, 7, e13938. [CrossRef]

26. Barr, D.; Gregson, W.; Reilly, T. The thermal ergonomics of firefighting reviewed. Appl. Erg. 2010, 41, 161-172. [CrossRef]

27. Ministry of Internal Affairs and Communications Fire Department. Available online: http://www.soumu.go.jp/main_content/ 000056809.pdf (accessed on 9 June 2021).

28. Cuddy, J.S.; Sol, J.A.; Hailes, W.S.; Ruby, B.C. Work patterns dictate energy demands and thermal strain during wildland firefighting. Wilderness Environ. 2015, 26, 221-226. [CrossRef] [PubMed]

29. Hagiwara, M.; Yamamoto, M. Systematic evaluation of the physiological load of mountain climbing from the relation between inclination of walking path, walking speed, and backpack weight: Simulation using walking on a treadmill. Jpn. J. Phys. Fit. Sports Med. 2011, 60, 327-341. [CrossRef]

30. Ndahimana, D.; Kim, E.K. Measurement methods for physical activity and energy expenditure: A review. Clin. Nutr. Res. 2017, 6, 68-80. [CrossRef] [PubMed] 